\title{
1 Exploring the effects of geotextiles in the performance of highway filter
}

\section{drains}

\author{
L.A. Sañudo-Fontaneda ${ }^{1 *}$, S.J. Coupe ${ }^{2}$, S.M. Charlesworth ${ }^{3}$, E.G.Rowlands ${ }^{4}$ \\ ${ }^{1}$ Department of Construction and Manufacturing Engineering. University of Oviedo. Polytechnic School \\ of Mieres. Calle Gonzalo Gutierrez Quiros s/n. 33600, Mieres (Asturias), Spain. Email: \\ sanudoluis@uniovi.es \\ ${ }^{2}$ Centre for Agroecology, Water and Resilience (CAWR), Coventry University, Ryton Gardens, Wolston \\ Lane, Ryton-on-Dunsmore, CV8 3LG, Coventry, UK. Email: steve.coupe@ coventry.ac.uk \\ ${ }^{3}$ Centre for Agroecology, Water and Resilience (CAWR), Coventry University, Ryton Gardens, Wolston \\ Lane, Ryton-on-Dunsmore, CV8 3LG, Coventry, UK. Email: sue.charlesworth@ coventry.ac.uk \\ ${ }^{4}$ Carnell Group Ltd. Gothic House, Market Place, ST19 5DJ, Penkridge, United Kingdom. Email: \\ gordon.rowlands@ carnellcontractors.com
}

"Corresponding author details: Email: sanudoluis@ uniovi.es

\section{Abstract}

Highway Filter Drains (HFD) are one of the most utilised drainage systems for roads, being considered as an environmental solution for sustainable drainage in transport infrastructures. However, little research has been done to understand their performance, representing a significant knowledge gap. This article therefore determines the hydraulic and clogging response of 3 different HFD designs in the laboratory; one standard design with British Standard Type B aggregate, and 2 new designs including a geotextile located at $50 \mathrm{~mm}$ and $500 \mathrm{~mm}$ depth from the surface of the HFD structure in order to assess the effect of the geotextile. The laboratory models were initially subjected to 9 rainfall scenarios with 3 rainfall intensities $(2.5,5$ and 10 $\mathrm{mm} / \mathrm{h}$ ) and 3 storm durations (5, 10 and 15 minutes). Subsequently, the equivalent of 2-years' worth of pollutants were added to test possible clogging issues under the highest intensity rainfall event, corresponding to a 1 in 1 year return period for the West Midlands, UK. No clogging issues were found in any of the models although the majority of the sediments were concentrated in the first $50 \mathrm{~mm}$ of the HFD 
profile, with higher percentages ( $>90 \%$ of the sediment added) in those models with an upper geotextile. Location of the geotextile significantly influenced $(\mathrm{p}$-value $=0.05)$ the hydraulic performance of the HFD.

Keywords: Geosynthetics; Clogging; Geotextile; Highway Filter Drains; Road Safety; Sustainable Drainage Systems (SuDS).

\section{Introduction}

Vehicle traffic in the UK has increased dramatically since the 1950s to more than 300 billion vehicle miles in 2014 (UK Department of Transport, 2015). To cope with this high volume of traffic, the UK has a road network of nearly $1.8 \mathrm{~km}$ road $/ \mathrm{km}^{2}$ of land area with a total length of $419,596 \mathrm{~km}$, of which $3,674 \mathrm{~km}$ are motorways and 49,040 km are main roads (Nicodeme et al. 2013).

The Strategic Road Network (SRN) (including motorways and A roads) (UK Department for Transport, 2012) and local road networks are England's most valuable infrastructure asset, valued at approximately $£ 344$ billion and as well as the roads, includes other infrastructure such as bridges, embankments and drainage systems (House of Commons, 2014). In 2012-2013 public spending on maintaining England's roads was $£ 4$ billion, divided between the UK Department of Transport, the Highways Agency (Highways England since 2015) and Local Authorities. The operation, maintenance and improvement of the SRN, which represents $2 \%$ of the total road network $(7,080 \mathrm{~km})$, is the responsibility of The Department of Transport through Highways England (House of Commons, 2014).

Road drainage systems are therefore a vital asset in transport infrastructure, contributing to the safety of road users by removing surface runoff, improving visibility and mitigating environmental problems to receiving waters. Hence, they are an important part of the maintenance programme developed by Highways England (Ellis and Rowlands, 2007; Coupe et al. 2015).

Filter Drains (FD), kerbs and gullies connected to pipes below ground and surface water channels along the pavement edge, are the main methods of dealing with surface runoff (DMRB-UK, 1997a). FD, also known as 'French Drains', are not only one of the most used drainage systems in the UK, but are also an historically important engineering technique across the world. FDs when used on highways are defined as Highway FD 
about 7,000 km accounting for traffic flow in both directions) uses HFD as their main drainage technique

(Coupe et al. 2015).

HFD are designed to cope with a wide range of storm events, to avoid flooding problems. Thus, the Design Manual for Roads and Bridges (DMRB-UK, 2004), Volume 4 Section 2 (Drainage), stipulates that highway drainage systems should be designed for high intensity events over a few minutes (short durations) with return periods of 1 year (with no surcharge of piped systems or road-edge channels) or 5 years with no flooding on the carriageway.

According to DMRB-UK, 1997b, UK HFDs should be a minimum of $0.6 \mathrm{~m}$ below the pavement sub-base in order to prevent groundwater entering the pavement structure. Including the full depth of the road structure, the typical depth for an HFD is up to $1 \mathrm{~m}$ with a width of approximately $1 \mathrm{~m}$ (Figure 1). A perforated pipe is located at a depth of $850 \mathrm{~mm}$ in a full-sized HFD, details and recommendations such as its diameter, the type of aggregate used for the bedding layer and the main body of the HFD are all given in the Design Manual for Roads and Bridges (DMRB-UK, 2001) and the UK Highways Agency Manual of Contract Documents for Highway Works (MCDH) (2009). After a long operational life, often 30 to 40 years of service, some HFD may need maintenance and in order to judge this, their performance is monitored using high-speed non-intrusive Ground Penetrating Radar (GPR) surveys, specifically SMARTscan both on verges and central reservations (Carnell, 2015). However, there is a lack of comprehensive understanding of the hydraulic processes that take place in HFDs and how resistant and resilient they are to flooding and clogging.

The impact of this research is wider than just the UK as HFD are used in other countries across the world such as the Republic of Ireland where a visual inspection carried by Bruen et al. (2006) on the Irish dual carriageways and motorways found that more than $40 \%$ of them had HFD as their main drainage system. Also in Ireland, issues around clogging have been commonly addressed by the use of a geotextile as a barrier to fine material ingress (Bruen et al. 2006; Desta et al. 2007) whilst still allowing water to flow through and into the drainage material and pipe. Other international drainage techniques similar to HFD also use geotextiles such as the so-called "edge drains" in the U.S.A (Kearns, 1992; Koerner et al., 1996) and Canada (Raymond et al. 2000); and also in Spain (Castro-Fresno et al. 2013; Andres-Valeri et al. 2014; Sañudo Fontaneda et al. 2016) where there are specifications including the use of geosynthetic products in drainage structures (AENOR, 2001; Bustos et al. 2007). 

Permeable Pavement Systems (PPS) in the UK (e.g. Pratt et al. 1999), their utilisation in association with HFDs is still viewed with scepticism by some engineers due to concerns over possible blockage of the aggregate layer and/or the pipe, leading to a reduction in infiltration capacity. In order to address these issues, there were 2 aims of this research:

1. To determine the effects on HFD hydraulic performance of the inclusion of geotextiles due to its water retention characteristic (WRC). This concept is described by Chinkulkijniwat et al. (2017), who also highlight the lack of knowledge of geotextile WRC.

\section{Materials and Methods}

97 2.1. Experimental preparation and materials

98 Ten plate-glass rigs were set up: 4 replicates of the Standard HFD, and three replicates for each HFD model containing geotextiles at 2 different depths in the profile $(50 \mathrm{~mm}$ and $500 \mathrm{~mm}$ respectively). The rigs had

$1005 \mathrm{~mm}$ thick walls and measured $215 \mathrm{~mm} \times 215 \mathrm{~mm}$ x $650 \mathrm{~mm}$, thus their volume was $0.030 \mathrm{~m}^{3}$ and surface area was $0.046 \mathrm{~m}^{2}$ (see Figure 2). No lower pipe was used, since the aim was to analyse the hydraulic and

102 clogging performance of the aggregate and to isolate the influence of the geotextile layer on the general performance of the HFD, following the preparation method presented in Sañudo-Fontaneda et al. (2017).

104 The outflow, used to build the hydrographs of performance for every HFD model, was measured using funnels placed at the bottom of each plate-glass rig to direct the outflow to a sample collector (see Figure 2).

107 The details of the materials used to replicate the three different HFD designs, as shown in Figure 2, are 108 presented below:

109 1. Standard HFD. Made of Type B aggregate (see Figure 2).

110 2. HFD + Lower Geotextile. As in the Standard HFD plus a geotextile layer at $500 \mathrm{~mm}$ depth from 111 the HFD surface and $50 \mathrm{~mm}$ from the base (see Figure 3).

112 3. HFD + Upper Geotextile. As in the Standard HFD above plus a geotextile layer at $50 \mathrm{~mm}$ depth from the surface (see Figure 3). 
114 The aggregate utilised in this study was that normally used in UK HFD installations and was 20-40 mm,

$115 \mathrm{G}_{\mathrm{c}}$ 85/20, clean Granodiorite Type B. A type B aggregate Particle Size Distribution (PSD) is presented in

116 Figure 2, complying with MCDH, 2009 and BS EN 13242 requirements (BSI, 2006).

117 The geotextile was a nonwoven fabric of virgin polypropylene fibres, with an approximate mass per unit

118 area of $0.13 \mathrm{Kg} / \mathrm{m}^{2}$. Nonwoven geotextiles have been widely used in roadworks and drainage due to their

119 supporting ability and improvement to the internal drainage of the aggregate layers (Sañudo Fontaneda et

120 al. 2016; Broda et al. 2017; Portelinha and Zornberg, 2017). This geotextile has been used previously in

121 research for example the TRAMMEL drainage system (Clapham, 1981; Ingold, 1994). It is also one of the

122 most widely used geosynthetics in Sustainable Drainage Systems (SuDS), especially PPS because of its

123 well-known pollutant removal efficiency in providing a suitable surface for trapping oil and allowing

124 microorganisms to grow (Newman et al. 2002; Coupe et al. 2003; Gomez-Ullate et al. 2010; Sañudo-

125 Fontaneda et al. 2014b). The hydraulic properties of the geotextile are given in Table 1.

126 This geotextile was also selected for its mechanical properties in terms of structural performance as it was

127 to be used at different depths in the HFD test rigs, and would therefore be subjected to different forces

128 (Table 2). The pressure generated by the weight of the aggregates perpendicular to the surface of the

129 geotextile would be $8.5 \mathrm{~Pa}$ in the case of a geotextile placed at $50 \mathrm{~mm}$ depth of the full scale HFD, and 85

$130 \mathrm{~Pa}$ at $500 \mathrm{~mm}$ depth, with a bulk density of $1.7 \mathrm{t} / \mathrm{m}^{3}$.

131 A rainfall/runoff simulator was specifically designed and built for the project (see Figure 3) and had the

132 following characteristics:

133 - Intensity range for direct rainfall: $50-400 \mathrm{~mm} / \mathrm{h}$.

134 - Surface: $0.0441 \mathrm{~m}^{2}(0.21 \mathrm{~m} \mathrm{x} 0.21 \mathrm{~m})$.

135 - $\quad$ Number of drippers: 9 (3 per row, total of 3 rows)

136 - Drop diameter: $3.5 \mathrm{~mm}$.

137 Flow was controlled in real time with a flowmeter on the water delivery pipe (see Figure 3), which 138 controlled rainfall intensity to between $50-400 \mathrm{~mm} / \mathrm{h}$ as required.

139

$140 \quad$ 2.2. Experimental methodology

141 There were 2 main stages: 
142 Stage 1. Hydraulic characterization of HFD performance was carried out by simulating flow produced by

143 three rainfall intensities $(2.5,5$ and $10 \mathrm{~mm} / \mathrm{h})$ raining over a draining area consisting of 2 carriageways and

144 a hard-shoulder (Table 3) and three storm durations (5, 10 and 15 minutes), resulting in 9 different storm

145 scenarios. The 1 in 1 year storm required for design of HFD by the DRMB (2004) was the highest rainfall

146 event simulated at this stage $1(10 \mathrm{~mm} / \mathrm{h})$ and the longest storm duration (15 minutes). A total of 90 tests

147 were carried out, 10 runs of each storm scenario, producing a total of 2,026 infiltration rate data points

148 (outflow measured per minute on each rig and each test). The Rational Method is suggested for SuDS

149 (Woods Ballard et al. 2015), therefore calculations were undertaken to determine the relationship between

150 rainfall intensities and the flow entering the models as a result of the surface runoff produced by these storm

151 events. Two and 3 carriageways are the most common number of lanes used on UK roads; this was the

152 justification for their use in calculating runoff flows (DMRB-UK, 1999).

153 Basing the calculations on the Rational Method, laboratory rainfall events of 100, 200 and $400 \mathrm{~mm} / \mathrm{h}$

154 (intensity values which will be used hereinafter for the analysis of the laboratory results) controlled by the

155 flowmeter connected to the rainfall/runoff simulator (see Figure 3) were generated over the surface of the

156 laboratory models $\left(0.046 \mathrm{~m}^{2}\right.$ surface area) in order to accomplish the rainfall scenarios and runoff flows

157 represented on Table 3.

158 Stage 2. Pollutants were periodically added to the rigs once Stage 1 was completed in order to simulate 2

159 years in-use of the HFD models, each rig was therefore subjected to the following conditions in terms of

160 pollutant addition:

161 Amount of sediment: $30 \mathrm{~g} / \mathrm{rig} / \mathrm{test}$ (i.e. $360 \mathrm{~g}$ added to each rig in total over the course of the 162 experiments) just before the addition of oil, representing sediment deposited on West Midland, UK

163 highways of approximately $1,000 \mathrm{~kg} / \mathrm{m} /$ year (Carnell Group Ltd., pers comm). The sediment was

164 obtained from arisings collected from gully pots connected to HFD pipes from a highway in the West

165 Midlands, UK. For each rig, 12 rainfall events of $10 \mathrm{~mm} / \mathrm{h}$ raining over a drainage area consisting of

1662 carriageways and a hard-shoulder of 15 minutes' duration (replicating the worst case scenario); a

167 total of 120 tests were carried out, producing a total of 2,739 infiltration measurements (outflow

168 measured per minute for each test). The intensity and storm duration used represented a 1 in 1-year

169 storm event in the West Midlands (UK) (Sañudo-Fontaneda et al. 2016), as required to avoid surcharge

170 in the pipe by the DMRB-UK 2004. The West Midlands was used as the reference for calculations, 
both from the amount of sediments and the rainfall volumes, due to the fact that there will be field studies undertaken in the future which will use the laboratory studies as comparators. The reason for using 2 years' worth of sediments was based on previous studies carried out by Mitchell (2015) in Scotland which indicated 2 years until the start of clogging issues, both in the surface layer and the pipe at the bottom of the HFD.

- Amount of oil: $6.121 \mathrm{~g} /$ rig/test $(74.58 \mathrm{~g}$ of oil was added to each rig in total over the course of the experiments) was based on Gomez-Ullate et al. (2010), Sañudo-Fontaneda et al. (2014b) and Bayon et al. (2015) who multiplied the suggested $9.27 \mathrm{~g} / \mathrm{year}^{\prime} \mathrm{m}^{2}$ by Pratt et al. (1999) by 100 to represent a

183 The effect of the inclusion of a geotextile layer on HFD performance was investigated using 2 main 184 approaches:

- Hydraulic performance of the HFD designs

$186 \circ$ Hydrographs of performance. The hydrographs were plotted at minute intervals using the volume of outflow measured in the sample collectors (Figure 3) from each rig under the different rainfall scenarios and then comparing the influence of the addition or not of geotextiles and pollutants. The outflow represented the infiltration rate for the whole HFD system simulated in the laboratory.

- Attenuation performance. Attenuation is considered to be the retention of rainfall in the HFD structure before production of the first outflow discharge during a storm event since the beginning of the rainfall event simulated. This could be affected by the presence or absence of a geotextile and hence was used to provide an indication of HFD performance. This time represented the capacity of each HFD design to delay commencement of discharge flow, and also the time to reach peak-flow.

- Geotextile effect on the hydraulic and clogging performance of HFD. Once the hydraulic performance of HFD was analysed, the effect of the inclusion of a geotextile in the HFD structure was analysed in isolation, including the study of potential clogging scenarios derived from the presence of the geotextile, as it is shown below: 

to assess the influence of the geotextile on the attenuation levels used to measure the hydraulic performance in the HFD designs.

- Geotextile effect on the potential for clogging on HFD. The accumulation of pollutants at different levels within the HFD structure measured from the surface was analysed in order to determine where the sediments preferentially deposited within the HFD structure. Once all the hydraulic experiments were finished, the sediments were carefully recovered from the laboratory models and weighed. The trapping efficiency of each HFD design was measured by weighing the sediments accumulated in the

\section{1} whole model profile at the end of all experiments and comparing them with the amount of sediments

\subsection{Hydraulic performance of the HFD designs (hydrographs and attenuation levels)}

213 Hydrographs of performance were produced for all storm durations (5, 10 and 15 minutes), including all

214 HFD designs (no geotextile, lower geotextile and upper geotextile) and laboratory rainfall intensities (100,

215200 and $400 \mathrm{~mm} / \mathrm{h}$ ). Figures 4, 5 and 6 show hydrographs for the 5 -minute storm duration only as the trends 216 for 10 and 15 minutes were similar.

217 Figures 5 and 6 show that, at the higher rainfall intensities (200 and $400 \mathrm{~mm} / \mathrm{h}$ ) the test rigs behaved in a

218 similar manner. However, at $100 \mathrm{~mm} / \mathrm{h}$ (Figure 4) there was more of a discrepancy between the rigs; those

219 with an upper geotextile in particular exhibiting lower rates than the others, as well as longer delays in both 220 the rising and falling limbs. Effluent took approximately 60 secs to be recorded after rainfall for the higher 221 rainfall intensities, but did not appear until 102 seconds in the rigs rained on at $100 \mathrm{~mm} / \mathrm{h}$. As intensity increased, the time to base flow reduced, and again at $100 \mathrm{~mm} / \mathrm{h}$ those rigs with the upper geotextile took

223 longer than any of the other rigs regardless of structure or rainfall intensity.

224 Regardless of rig structure, Figure 7 shows that at the lower rainfall intensities peak flow was achieved at 225 the same time, approximately 300 seconds. However, for the higher rainfall intensities, the structures behaved slightly differently, with all 3 taking less time to peak than at lower intensities. Those with no 
geotextile reached the peak more quickly than those with a lower geotextile which were quicker than rigs with an upper geotextile.

229 In order to assess the statistical significance of geotextile location, duration of the simulated rainfall and its

230 intensity, statistical testing was undertaken. A Kolmogorov-Smirnov test was carried out in order to check

231 whether the data were normally distributed. The potential influence of the presence of a geotextile on

232 hydraulic performance was analysed using ANOVA for parametric variables (normally distributed) with k-

233 samples (3 for geotextile location: no geotextile, lower geotextile and upper geotextile). ANOVA was also

234 used to check the statistical significance of storm duration on attenuation, and the influence of rainfall

235 intensity on attenuation performance was tested using Kruskal Wallis. Table 4 summarises the results of

236 these statistical tests, showing that geotextile location had a significant influence on attenuation, as did

237 rainfall intensity, both at the $95 \%$ confidence level. However, storm duration was found not to significantly

238 affect attenuation performance.

239 Table 5 shows the impact of rig structure and rainfall intensity on attenuation performance through the use

240 of equations of performance (trends). The values of $\mathrm{R}^{2}$ for the rigs without a geotextile and those including

241 a lower geotextile were $>0.70$, whilst that for the rigs with an upper geotextile was $>0.5$.

\subsubsection{Stage 2: the effect of pollutant addition on HFD performance}

244 That the addition of pollutants did influence hydraulic performance is illustrated in Figure 8 which shows 245 that the capacity of the system was reduced in terms of its ability to attenuate the storm peak. Sediments

246 also introduced higher variability as it can be seen in the number of outlayers within the experiments. This

247 particular behaviour from the sediments was highlighted by Sañudo-Fontaneda et al. (2013) when studying

248 the reduction of the infiltration capacity of PPS under different clogging scenarios.

249 It was also found that geotextile position influenced hydraulic performance (Figure 9) since the time to

250 peak for all models was increased from no geotextile structures to an upper geotextile. This finding suggests

251 that designers and practitioners looking for an increase in the time to peak should include the geotextile

252 closer to the surface of the HFD.

2543.2 Geotextile effect on the hydraulic and clogging performance of HFD

$255 \quad$ 3.2.1 Geotextile effect on the hydraulic performance of HFD 

attenuation performance and the addition of sediments at a 95\% confidence level as well as high correlation between attenuation, rainfall intensity, storm duration and geotextile location.

In order to confirm these preliminary findings, a Kruskal Wallis test was carried out to compare the

260 influence of the inclusion of a geotextile on hydraulic performance using attenuation levels, whilst a Mann-

261 Whitney test was performed to validate the influence of sediment addition on hydraulic performance. The

262 results are shown in Table 7 which confirmed that the addition of sediments and the presence of a geotextile

263 had a statistically significant effect on hydraulic performance.

3.2.2 The presence of a geotextile and its effect on the potential for clogging

266 No clogging issues were observed during storm events that simulated 2-years' worth of pollutant addition

267 (sediments and oil) over the laboratory models although the hydraulic behaviour was found to be different.

268 Eventually, however, a crust of oil and sediment developed on the rig surface and began to create an

269 impermeable layer preventing the downprofile migration of the sediment as found in other studies such as

270 Mitchell (2015).

271 It was found that the pollutants preferentially accumulated in the top $50 \mathrm{~mm}$ of the HFD profile despite the

272 presence of geotextile as can be seen in Table 8. More than $70 \%$ of the total amount of pollutants added to

273 the models were found in the top of the profile for rigs either without a geotextile, or with one located lower

274 in the profile. However, $98.2 \%$ of the pollutants were found at the top of the profile for rigs with an upper

275 geotextile. Whilst complete clogging of the system was not an issue over the course of the experiments, nonetheless the likelihood would be that the rigs with an upper geotextile would eventually clog, and more

277 quickly than the other structures being tested. In fact, Zhao et al. (2016) found that nonwoven geotextiles 278 are beneficial in providing a groundwater drainage layer. However, there are other possible variables

279 influencing the loss of hydraulic capacity in the field such as chemical clogging (Veylon et al. 2016).

280 Based on this study, the hydraulic deterioration of geosynthetics should be addressed in long-term field

281 studies in order to quantify the potential for clogging when used in an HFD. Furthermore, Yoo (2016)

282 pointed out the need to understand the hydraulic deterioration of geosynthetic filter drainage systems for

283 their use in other civil engineering structures such as tunnels. 


\section{Conclusions}

286 This research has shown that using a geotextile in an HFD can contribute positively to improve the safety

287 of highways since peak flow is delayed as is time to peak due to the geotextile's ability to become wet 288 whilst maintaining a head of water before allowing it to pass through (WRC).

289 Increasing rainfall intensity influenced the hydraulic performance of HFD rigs by decreasing time to peak

290 in all designs. However, storm duration did not influence peak attenuation in any of the HFD designs,

291 although it did affect the volume of runoff infiltrated. In addition, the presence of a geotextile influenced

292 hydraulic performance by increasing peak attenuation, hence delaying the time to peak in comparison with

293 rigs without a geotextile. Moreover, the position of the geotextile layer influenced hydraulic performance

294 (p-value $=0.05$ ), with the higher geotextile exhibiting longer times to peak, followed by the lower 295 geotextile; rigs without a geotextile had the shortest time to peak.

296 The addition of pollutants (sediments and oil) significantly influenced hydraulic performance of all designs,

297 reducing the capacity for infiltration with the eventual formation of an impermeable crust at the surface of

298 the rigs. The majority of applied pollutants preferentially accumulated higher in the HFD profile in the top

$29950 \mathrm{~mm}$, confirming the findings of previous studies such as Mitchell (2015) and Coupe et al. (2015).

300 Furthermore, the presence of an upper geotextile trapped more than 95\% of the applied pollutants in the top

$30150 \mathrm{~mm}$ of the profile in comparison with the lower geotextile (75.9\%) and no geotextile (72.4\%). Finally,

302 no clogging was observed as a result of the addition of 2 years' worth of sediment.

303

\section{Acknowledgements:}

305 The authors would like to thank Carnell Support Services Ltd for funding the study. Luis A. Sañudo-

306 Fontaneda also wish to thank the funding for the development of the UOStormwater Engineering Research

307 Team by the University of Oviedo through the research project with reference PAPI-17-PEMERG-22. 


\section{References}

310 AENOR, 2001. UNE-EN 13252:2001. Geotextiles and geotextile-related products. Characteristics required 311 for use in drainage systems.

312 Andrés-Valeri, V.C.A., Castro-Fresno, D., Sañudo-Fontaneda, L.A., and Rodriguez-Hernandez, J., 2014.

313 'Comparative analysis of the outflow water quality of two sustainable linear drainage systems'. Water $314 \quad$ Science and Technology, 70 (8), 1341-1347.

315 Bayon, J.R., Jato-Espino, D., Blanco-Fernandez, E., Castro-Fresno, D., 2015. Behaviour of geotextiles designed for pervious pavements as a support for biofilm development. Geotextiles and Geomembranes, 43 (2), 139-147.

British Standards Institution (BSI), 2006. BS EN 13242: Aggregates for unbound and hydraulically bound materials for use in civil engineering work and road construction. London: BSI.

Broda, J., Gawlowski, A., Laszczak, R., Mitka, A., Przybylo, S., Grzybowska-Pietras, J., Rom, M., 2017. Application of innovative meandrically arranged geotextiles for the protection of drainage ditches in the clay ground. Geotextiles and Geomembranes, 45 (1), 45-53.

Bruen, M., Johnston, P., Quinn, M.K., Desta, M., Higgins, N., Bradley, C., and Burns, S., 2006. "Impact Assessment of Highway Drainage on Surface Water Quality”. Report prepared for the Environmental protection Agency by the Centre for Water Resources Research, University College Dublin.

Bustos, G. and Pérez, E., 2007. Pliego de prescripciones técnicas generales para obras de carreteras y puentes. 5th Edition. Ediciones LITEAM. Madrid, Spain.

328 Carnell, 2015. SMARTscan. http://www.carnellgroup.co.uk/Services/Drainage2/SMARTscan/

329 Castro-Fresno, D., Andrés-Valeri, V.C., Sañudo-Fontaneda, L.A., and Rodriguez-Hernandez, J., 2013.

330 'Sustainable drainage practices in Spain, specially focused on pervious pavements.' Water, 5 (1), 6793.

332 Chinkulkijniwat, A., Horpibulsuk, S., Bui Van, D., Udomchai, A., Goodary, R., Arulrajah, A., 2017. 333 Influential factors affecting drainage design considerations for mechanical stabilised earth walls using 334 geocomposites. Geosynthetics International, 24 (3), 224-241.

335 Clapham, H.G., 1981. The TRAMMEL Drainage System. Transport Research Laboratory. American 336 Society of Civil Engineers (ASCE). 24-26 pp. 

within permeable pavements. European Journal of Protistology, 39 (4), 495-498.

Coupe, S. J., Sañudo-Fontaneda, L. A., Charlesworth, S. M., Rowlands, E. G. Research on novel highway filter drain designs for the protection of downstream environments. SUDSnet International

from: http://sudsnet.abertay.ac.uk/SUDSnetConf2015.htm. retention and in-situ treatment of contaminated sediments in laboratory highway filter drain models. Water Efficiency Network Conference (WATEFCON 2016). Water Frontiers: Strategies for 2020 and

Desta, M.B., Bruen, M., Higgins, N., and Johnston, P., 2007. Highway runoff quality in Ireland. Journal of Environmental Monitoring, 9, 366-371.

DMRB-UK, 1996. Design Manual for Roads and Bridges: Geotechnics and Drainage. Vol. 4, sec. 2, part

DMRB-UK, 1997a. Design Manual for Roads and Bridges: Geotechnics and Drainage. Vol. 4, sec. 2, part Agency, UK.

DMRB-UK, 1997b. Design Manual for Roads and Bridges: Geotechnics and Drainage. Vol. 4, sec. 2, part

4. (HA 79/97). Edge of pavement details for porous asphalt surface courses. Technical Report, Highways Agency, UK.

DMRB-UK, 1999. Design Manual for Roads and Bridges: Traffic Capacity of Urban Roads. Vol. 5, sec. 1, part 3. (TA 79/99 Amendment No 1).

DMRB-UK, 2001. Design Manual for Roads and Bridges: Geotechnics and Drainage. Vol. 4, sec. 2, part Report, Highways Agency, UK. 
DMRB-UK, 2004. Design Manual for Roads and Bridges: Geotechnics and Drainage. Vol. 4, sec. 2, part UK.

Ellis, J.B., Rowlands, E.G., 2007. Highway filter drain waste arisings: A challenge for urban source control management? Water Science and Technology, 56 (10), 125-131.

Gomez-Ullate, E., Bayon, J.R., Coupe, S., Castro-Fresno, D., 2010. Performance of pervious pavement parking bays storing rainwater in the north of Spain. Water Science and Technology, 62(3), 615-621.

House of Commons, 2014. Maintaining strategic infrastructure: roads. Fifteenth Report on Session 20142015. Committee of Public Accounts. London: The Stationery Office Limited. http://www.publications.parliament.uk/pa/cm201415/cmselect/cmpubacc/105/105.pdf.

Ingold, T.S., 1994. Prefabricated fin drains and their application. Geotextiles and Geomembranes: Manual. Elsevier Advance Technology, UK.

Kearns, R.E., 1992. Long-term performance of geocomposites used as highway edge drains. Geotextiles and Geomembranes, 11(4-6), 513-521.

Koerner, G.R., Koerner, R.M., Wilson-Fahmy, R.F., 1996. Field performance of geosynthetic highway drainage systems. ASTM Special Technical Publication, 1281, 165-180.

MCDH, 2009. Manual of Contract Documents for Highway Works. Volume 1 - Specification for Highway Works. Series 500: Drainage and Service Ducts. Highways Agency, UK.

Mitchell, G., 2015. Clogging of filtration SUDS. Long term performance of trunk road filter drains. SUDSnet International Conference, Coventry, UK, 2015. Available from: http://sudsnet.abertay.ac.uk/documents/SUDSnet2015_Mitchell_CloggingofFiltrationSuDS.pdf.

Newman, A.P., Pratt, C.J., Coupe, S.J., Cresswell, N., 2002. Oil bio-degradation in permeable pavements

Nicodeme, C., Diamandouros, K., Diez, J., Durso, C., Brecx, C., Metushi, S., 2013. European Union Road Federation. European http://www.irfnet.eu/images/Statistics/ER_Statistics_Final_2012.pdf. geotextile-reinforced soil wall. Geotextiles and Geomembranes, 45(3), 211-226. 
Pratt, C.J., Newman, A.P., Bond, P.C., 1999. Mineral oil big-degradation within a permeable pavement: Long term observations. Water Science and Technology, 39(2), 103-109.

Raymond, O.P., Bathurst, R.J., Hajek, J., 2000. Evaluation and suggested improvements to highway edge drains incorporating geotextiles. Geotextiles and Geomembranes, 18(1), 23-45.

Sañudo-Fontaneda, L.A., Rodriguez-Hernandez, J., Vega-Zamanillo, A., Castro-Fresno, D., 2013. Laboratory analysis of the infiltration capacity of Interlocking Concrete Block Pavements in car parks. Water Science and Technology 2013, 67(3), 675-681.

Sañudo-Fontaneda, L.A., Andrés-Valeri, V.C.A., Rodriguez-Hernandez, J., and Castro-Fresno, D., $2014 a$. Field study of the reduction of the infiltration capacity of porous mixtures surfaces tests. Water, 6 (3), 661-669.

Sañudo-Fontaneda, L.A., Charlesworth, S., Castro-Fresno, D., Andrés-Valeri, V.C.A., and Rodriguez-

Sañudo Fontaneda, L.A., 2014. The analysis of rainwater infiltration into permeable pavements, with concrete blocks and porous mixtures, for the source control of flooding. PhD Thesis, University of

Sañudo-Fontaneda, L.A., Jato-Espino, D., Lashford, C., Coupe, S.J., 2016. Investigation of the design considerations for Highway Filter Drains through the comparison of stormwater management tools with laboratory simulation experiments. 9th International Conference NOVATECH. Planning \& Technologies for Sustainable Urban Water Management. Lyon, France. Fresno, D., 2016. Use of Geosynthetics for Sustainable Drainage. Book chapter in "Sustainable

417 Sañudo-Fontaneda, L.A., Jato-Espino, D., Lashford, C., Coupe, S.J., 2017. Simulation of the hydraulic 418 performance of highway filter drains through laboratory models and stormwater management tools. 419 Environmental Science and Pollution Research, 1-10. Article in Press.

420 UK Department for Transport, 2012. Guidance on Road Classification and the Primary Route Network. 
$423 \quad$ classification-guidance.pdf.

424 UK Department of Transports, 2015. National Road Traffic Survey.

425 https://www.gov.uk/government/statistical-data-sets/tra01-traffic-by-road-class-and-region-miles.

426 Veylon, G., Stoltz, G., Mériaux, P., Faure, Y.-H., Touze-Foltz, N., 2016. Performance of geotextile filters

427 after 18 years' service in drainage trenches. Geotextiles and Geomembranes, 44 (4), pp. 515-533.

428 Woods Ballard, B., Wilson, S., Udale-Clark, H., Illman, S., Ashley, R and Kellagher, R., 2015. The SuDS manual, CIRIA 753. CIRIA. ISBN 979-0-86017-760-9.

430 Yoo, C., 2016. Hydraulic deterioration of geosynthetic filter drainage system in tunnels - its impact on 431 structural performance of tunnel linings. Geosynthetics International, 23(6), 463-480.

432 Zhao, A., Oelkers, C., Diviacchi, V., 2016. Geocomposite for landfill's groundwater drainage layer. Geosynthetics, 34(1). 